\title{
Maps for developing information competency of sportsman students in conditions of digital transformation
}

\author{
NATALIA P. TABACHUK ${ }^{1} \triangle$, NATALIA V. SOFRONOVA2 ${ }^{2}$ ANATOLII E. POLICHKA ${ }^{1}$, NADEZHDA A. \\ SHULIKA ${ }^{3}$, ELENA V. KADURA ${ }^{3}$ \\ ${ }^{1}$ Department of Mathematics and Information Technologies, Pacific National University, Khabarovsk, Russian \\ Federation \\ ${ }^{2}$ Department of Informatics and Information and Communication Technologies, I. Yakovlev Chuvash State Pedagogical \\ University, Cheboksary, Russian Federation \\ ${ }^{3}$ Department of Higher Mathematics, Far Eastern State Transport University, Khabarovsk, Russian Federation
}

\begin{abstract}
The progress to "cloud-based learning" and transition to "personalized learning" occur within digital transformation of education. Within this context, the authors analyse regulatory documents and recommendations outlined by the professional, teaching, and psychological communities and making the research relevant. The research question put up in the paper is: how to plot maps for developing the information competency of students in conditions of digital transformation. Theoretical substantiation is presented for the following phenomena under study: digital transformation, mapping, individual educational path, the information competency of students. It is pointed out that mapping is the process of creating maps for reducing the unpredictability effect and solving the problem of choice, a way of visualization of the future, and a strategy of one's self-development. It is highlighted that the individual educational route is the authors' approach to self-fulfilment in the real and virtual world. They describe the approach to understanding the student information competency as the key meta-subject educational one. This competency consists of the cognitive, motivational, and activity-based components which are provided with details by students via "understanding", generating their own meanings, and enriching their subject experience. In the paper, the stages of pedagogical support and fulfilment of maps for developing the said competency are described, too: the ascertaining one, transforming, and analytical ones. The pedagogical experience of mapping is summed up which is associated with the students' plotting and fulfilling various types of maps outlined by the authors: subject maps, meta-subject (mental) maps, portfolio maps as the digital footprint, start-up maps. The total of various maps represents the databases and analytical methods of their research. For studying the former, the authors used the expert appraisal method and applied some psychological techniques. The principal research results can be summarized by the statement: in the period of digital transformation and the pandemic, maps have to be plotted for settling emotions in conditions of lockdown and uncertainty, for supporting the relevant student initiatives, and for shaping their profound unmistakable "digital footprint", which characterizes the students' high information competency development level.
\end{abstract}

Keywords: Sportsman students; Digital transformation; Mapping; Individual educational route; Information competency of students.

Cite this article as:

Tabachuk, N.P., Sofronova, N.V., Polichka, A.E., Shulika, N.A., \& Kadura, E.V. (2021). Maps for developing information competency of sportsman students in conditions of digital transformation. Journal of Human Sport and Exercise, 16(3proc), S1293-S1307. https://doi.org/10.14198/jhse.2021.16.Proc3.45

Corresponding author. Department of Mathematics and Information Technologies, Pacific National University, Khabarovsk, Russian Federation.

E-mail: tabachuk@yandex.ru

Abstract submitted to: Winter Conferences of Sports Science. Costa Blanca Sports Science Events, 22-23 March 2021. Alicante, Spain.

JOURNAL OF HUMAN SPORT \& EXERCISE ISSN 1988-5202.

(C) Faculty of Education. University of Alicante.

doi:10.14198/jhse.2021.16.Proc3.45 


\section{INTRODUCTION}

The authors share the standpoint of the Russian scientist I.V. Robert (2020) who considers digital transformation of education as a foundation for the digital paradigm of education to be established and developed upon, as a result of the process of changes occurring in the domain of education when digital technologies are extensively used for educational purposes.

In the era of digital transformation of education, a new variant of educational information interaction on the subject-to-subject basis is created by means of digital technologies - the digital educational environment as an ecosystem for students to "absorb" universal and professional competencies, one of them being the information competency.

The impact of digital transformation of education extends to the information competency development process as for higher educational institution students, too, which initiates the transition to "personalized learning". Within it, attention is paid to building individual educational routes of students' participation in the digital educational environment.

Based on their analysis of studies of both Russian and foreign scientists in the domain of digital transformation of education, promising lines of the development of computer science (Karakozov \& Uvarov, 1916; Sofronova \& Belchusov, 2019; Tulchinskiy, 2017; Ovsyanitskaya, 2018; Smakotina, 2017; Agheev et al., 2017; Bubnova et al., 2018; Soltovets et al., 2019; Bayanova et al., 2019; Soltovets et al., 2020; Bayanova et al., 2020; Abad-Segura et al., 2020), the authors are convinced of the fact that the student information competency has to exceed the current nomenclature of competencies - for having an early edge in the situation and preadaptation as important aspects manifesting themselves in the period of the pandemic.

The analysis of sources of the Scientific Russia information portal according to their description of the particularities of existence in the period of the pandemic shows that scientists, journalists, and public figures note the general trends of the transformation processes:

- Transition to the stepped-up digital transformation of education;

- Revealing of cultural, ethic, and psychological aspects associated with the particularities of experiencing lockdown and uncertainty, with possible responses being tiredness, stress, anxiety, unease, uncertainty, and fear one can develop (Portal "Scientific Russia", 2020).

For higher educational institution students, such a combination can generate stress reaction. There are various ways for relieving the stress situation within the educational process.

One of them is mapping as the process of plotting maps of the student information competency development, with individual educational routes being determined and positive visualization provided for.

In this case, stress is compensated for by the way of thinking aimed at students' individual life objectives. Planning and consciously turning to known positive facts can reduce anxiety, creating conditions for psychological stability and developing the student information competency as the meta-subject, universal, and important one in the period of digital transformation.

For building maps as images of the future, one has to overcome limitations of adaptive models and turn to preadaptation as the navigation strategy of developing systems from the standpoints of Russian scientists A.G. Asmolov, E.D. Shekhter and A.M. Chernorizov (2017). 
These scientists note that preadaptation to uncertainty which manifests itself brightly in the period of the pandemic can be accomplished by means of transition from the "mode of trends" (anticipating changes based on the past experience) to the innovative "mode of constructing other worlds".

It can be argued that students' preadaptation to uncertainty is associated with their selection of individual educational routes and laying them out using maps.

In this context, research works by a number of scientists are of interest (Khutorskoy, 2005; Yakimanskaya, 2007; Abulkhanova, 2014; Kutuev et al., 2017; Kovaleva et al., 2018; Prokofieva et al., 2018). They detail the essence of understanding of the phenomenon "individual educational route" and put up problems of individualizing and personalizing students' learning, searching for variants of educational routes, and "plunging" into this kind of activity.

With the said facts, the authors highlight the relevance of the question under study addressed to in this paper: how to build maps for developing the information competency of students in conditions of digital transformation, while also performing pedagogical support and fulfilment of the maps. The research in this focus area is made relevant by a number of regulatory documents and recommendations outlined by the professional, teaching, and psychological communities.

\section{Literature review}

In the era of digital transformation, discussion panels for the professional, teaching, and psychological communities to join in are set up.

Within these discussion panels and professional dialogs, new contexts are formed in substantiating the phenomena of digital transformation, the pandemic, mapping, the individual educational route, and the information competency of students (Vinogradova et al., 2018; Podymov et al., 2019; Orekhovskaya et al., 2019; Khairullina et al., 2020).

A number of regulatory documents and recommendations emphasize the importance of cultivating one's information competency, rendering pedagogical support, and a person's fulfilling his or her individual educational route (Kardis et al., 2019; Avdeev et al., 2019; Makarova et al., 2019; Piralova et al., 2020). They also describe recommendations and actions in conditions of the pandemic.

To such regulatory documents, one can refer the Passport of the national project "Education" (Passport of the national project "Education", 2019), guidelines by UNESCO "ICT competency framework for teachers" (2019), Atlas of new professions (2020), and recommendations of the Russian Psychological Society (Recommendations of the Russian Psychological Society due to the spread of COVID-19, 2020).

The Passport of the national project "Education" (2019) emphasizes the necessity of developing an individual's information competency by a number of provisions to be fulfilled within 2019-2024:

- Development of the "Federal information and service platform of the digital educational environment" for continuous education;

- Creation of "centres of personal digital education";

- Creation and upgrade of open digital educational resources;

- Construction of the "target model of the digital educational environment", which implies streamlining the process of developing the learner's personal information competency (Passport of the national project "Education", 2019). 
The analysis of the principal provisions of the project passport shows that in the current conditions of digital transformation, it is the needs of developing the following abilities that go to the forefront within the tasks of elaborating the educational system of higher educational institutions:

- Abilities to fulfil individual educational routes based on the lifelong education principles;

- Abilities to exist within the cyberspace and the competitive digital educational environment of higher educational institutions;

- Abilities to create and apply state-of-the-art educational, information, and digital technologies for solving professionally relevant problems, which implies achieving a high development level in terms of the student information competency.

Pedagogical initiatives and innovations for achieving the high information competency level are described in the UNESCO guidelines "ICT competency framework for teachers" (2019). They put up questions of the efficient integration of the ICT into the educational and professional practice for all subjects of the educational process to succeed in conditions of digital transformation. These recommendations can be viewed as a threetiered map of educational routes along the following lines:

- Knowledge acquisition: teachers acquire knowledge about the use of technologies and get basic ICT-competencies;

- Knowledge deepening: teachers gain ICT-competencies which will enable them to create a favourable educational environment in the future oriented to students and the development of teamwork skills;

- Knowledge creation: teachers gain competencies helping them model advanced practices and create the digital educational environment which would promote the formation of new knowledge in learners; the knowledge is essential for the development of digital society (ICT competency framework for teachers, 2019).

Professional initiatives and innovations can be discussed and are recorded in the Atlas of new professions (2020) which as of today lists many professions associated with creation of personal educational path maps. So, the following important professions are singled out for the domain of education: developer of educational paths, tutor, start-up mentor, and others (Atlas of new professions, 2020).

Recommendations of the Russian Psychological Society due to the spread of COVID-19 (2020) describes approaches of psychological support for personality in conditions of uncertainty, organizing distance learning, maintaining motivation and involvement of students in the current distance learning, etc.

For this research, from the above guidelines, the point can be quoted that "ways of overcoming stress in the period of the pandemic are time management in conditions of social distancing or lockdown, receiving the timely information, and rethinking it" (Recommendations of the Russian Psychological Society due to the spread of COVID-19, 2020).

Having analysed the modern regulatory documents and guidelines, the authors are convinced of the importance of mapping, building individual educational routes and developing the information competency of students in conditions of digital transformation and the pandemic.

Within the context of searching for in-depth meanings of the said phenomena (digital transformation, mapping, individual educational route, students' information competency), the authors turned to works of both Russian and foreign scientists and provided theoretical substantiation for approaches to exploring these phenomena. The findings are presented in the Results and discussion section. 


\section{MATERIALS AND METHODS}

The objective of the research consists in theoretical substantiation, practical elaboration, testing out, and experimental test of the efficiency of constructing maps for developing the information competency of higher educational institution students in conditions of digital transformation and the pandemic.

The research question put up in the paper is: how to build maps for developing the information competency of students in conditions of digital transformation and the pandemic, while also rendering pedagogical support and ensuring fulfilment of the maps.

The research hypothesis is as follows: the process of developing the information competency of higher educational institution students will be more efficient in conditions of digital transformation and the pandemic if mapping is used as a system of assistance and support for individual educational routes as the authors' approach to self-fulfilment both in the real and virtual world.

The tasks of the research are:

1. Describing the current challenges to civilization: digital transformation and the pandemic.

2. Identifying regulatory documents and recommendations outlined by the professional, teaching, and psychological communities.

3. Providing theoretical substantiation for approaches to studying the phenomena of digital transformation, pandemic, mapping, individual educational route, and students' information competency.

4. Working out in practice the stages of plotting maps for developing the information competency of higher educational institution students, finding out the types of maps.

5. Describing the experience of rendering pedagogical support to the university students in mapping and their fulfilling different map types.

6. Testing by experiment the efficiency of constructing maps in completing the types of individual educational routes in the information competency development process in students.

The total of various maps built by students during the pandemic represents the databases and analytical methods of their research. For studying the former, the authors used the expert appraisal method and applied some psychological techniques (llyina, 2020) technique for studying the motivation of learning at higher educational institutions, the technique for identifying the reflexivity development level by A.V. Karpova (2020).

The stages of pedagogical support and fulfilment of maps for developing the student information competency are described below: the ascertaining stage, the transforming, and analytical ones.

\section{RESULTS AND DISCUSSION}

Theoretical substantiation of approaches to studying digital transformation, mapping, individual educational routes, and the student information competency as phenomena

Digital transformation of education is the object of research for many Russian and foreign scientists who detail its various facets.

So, S.D. Karakozov and A.Yu. Uvarov (2016) note that during digital transformation of education, people advance to "cloud-based education" of various levels, the openness of digital educational resources is 
ensured, and what takes place is transition to "personalized learning", as a student turns from a knowledgeabsorbing subject to the subject of information interaction within the digital educational environment.

G.L. Tulchinskiy (2017) associates digital transformation with the processes of "containment breaking" of education to mean education going beyond the university classrooms.

L.Yu. Ovsyanitskaya (2018) defines digital transformation in the range of fulfilment of the strategic national priorities where digitized data become the key mobility factor in the professional activity.

N.L. Smakotina (2017) singles out opportunities and risks of digital transformation of education. She notes that digital transformation of education is an important investment for the future prosperity but its propagation leads to a new trend emerging - "McDonaldization of education" with its motto - "Stylish. Speedy. Light".

In the study by scientists E. Abad-Segura et al. (2020), they emphasize that digital transformation in the education sector implies involvement of sustainable management to adapt to changes caused by new technologies.

The same point is highlighted in the research of A.I. Agheev et al. (2017) who note that a new level of digital transformation can be identified that ensures the creation of high-tech infrastructure (digital space) demanding the high information competency development level.

Notably, the modern studies of digital transformation of education pay attention to challenges and risks of this process. They trace down the relationship of digital transformation and the student information competency development process.

The era of the pandemic affects the development and self-development of personality, too, in various terms, and it implies the transition from adaptive behaviour models to the "preadaptation to uncertainty".

Concerning this, some important points from speeches of experts are noted on the Scientific Russia information portal. They note that in the period of the pandemic, one must teach living in conditions of uncertainty and looking for positive facts in the lockdown through a bunch of productive strategies (maps) for maintaining one's psychological well-being. One has to consider lockdown not only as a self-limitation situation, but as an opportunity for self-development (Portal "Scientific Russia", 2020).

For this research, it is important to understand that while adaptations are up to the requirements of the already formed environment which gradually alters within some settled norms, preadaptation emerge before they are actually needed. They can be potentially of use in the future only under so far unknown, but considerably different from the previous ones, conditions of existence, which is the case to be observed in the period of the pandemic (Huxley, 1942).

So, extrapolating the provisions of L. Cuénot's (1914) preadaptation theory, one can argue that the meaning of preadaptation (in the form of qualities not sought after at present) consists in their enabling students not to passively follow the digital educational environment, but to look for new ways of building their individual educational routes (mapping). It is this creative search that is the source of self-development of the information competency in students. 
The approach of T.M. Kovaleva et al. (2018) is of interest; they define mapping as the process of working with maps which is always launched in the joint work of students and teachers. It is subsequently continued and maintained by students on their own, becoming an important tool of "organizing themselves" for them, the process of their personal mapping.

In the authors' understanding, mapping is the process of creating maps for reducing the unpredictability effect and solving the problem of choice, the way of visualizing the future, and the strategy of personal selfdevelopment of students.

In recent years, students' aspiration to build their individual educational routes, with life references and the personal element prevailing, has been seen more and more clearly.

There are various interpretations of this phenomenon to be found: personal life path, life strategy (Abulkhanova, 2014), individual educational path (Khutorskoy, 2005), individual training strategy (Yakimanskaya, 2007), individual educational route (Yurlovskaya \& Guchmazova, 2016).

K.A. Abulkhanova (2014) developed the typological strategy of studying the personality. Based on it, the highest personal abilities associated with the life path have been studied - the time management ability, the activity and initiative one, responsibility, the integral of aspirations, self-regulation, and satisfaction. These abilities underlie the personal life path.

A.V. Khutorskoy's (2005) definition is as follows: "Individual educational path is a learner-specific way of fulfilment of the personality potential of each learner in education".

By the individual educational route, I.A. Yurlovskaya and K.P. Guchmazova (2016) mean the personal events-related way of continuous personal development and fulfilment of the potentials of students in the educational process at higher educational institutions, according to their personal preferences, motives, and interests.

So, various approaches to defining the "individual educational route" phenomenon have been analysed. Let it be specified that for the authors, this involves their own approach to self-fulfilment both in the real and virtual world. It proceeds from one's own educational motives and interests and relies on the subject experience, initiative, and personal strategies of fulfilment of one's plans.

The following meanings of the notion of the information competency of higher educational institution students are intended by the authors: this is the universal, meta-subject, educational competency consisting of the cognitive, motivation, and activity-based components. These are provided with details by students via "understanding", generating their own meanings, and enriching their subject experience (Tabachuk, 2019). The competency touches on the domains of working with information as a source of new knowledge (Tabachuk, 2016). Also, the information competency references of existence in the cyberspace and the competitive digital educational environment; situations of independently learning the new using digital technologies. It is also about the problem of manifesting the Internet activity without turning it into the Internet addiction in the digital space and exploring new aspects of self-fulfilment and self-improvement of higher educational institution students.

It is maps that serve as the tool for cultivating the information competency. In particular, these are maps for generating new and modern ideas of student start-ups; for maintaining the relevant student initiatives at all 
levels of education at higher educational institutions; for shaping the profound unmistakable "digital footprint" of students. The maps are also essential for manifesting the students' research and project activity in the learning activity products; for developing the students' ability to extract the necessary information from the digital content, and for avoiding the "content blindness" (Robert, 2020), i.e., the inability to understand information consciously when perceiving and using it. All the above characterizes and maintains the high information competency level in students.

\section{Stages of plotting maps for developing the student information competency. Types of maps}

In this research, let the stages of pedagogical support and fulfilment of maps for cultivating the student information competency be described, in particular: the ascertaining one (when the motivation and reflective constituents of the said competency are diagnosed; they are important for completing individual educational routes), the transforming one (the system of mapping is introduced into the educational process), and the analytical stage (experimental test of the efficiency of constructing maps for completing the types of individual educational routes in the information competency development process in higher educational institution students).

When it comes to mapping, the question of the development priorities arises.

In the process of mapping, there are the following priorities: relying on the subject experience of selfdevelopment of the information competency; the presence of a mentor teacher; taking into account students' motives, interests, and preferences and describing the desired level in detail (the target skills map); supporting the initiatives and innovations; cultural context in the development of the information competency of higher educational institution students as the meta-subject one.

As it was noted in the earlier studies, the latter is formed through understanding the cultural constituent of the information competency. Accordingly, this serves for upgrading the culture of working with information (the information culture), presenting the information in a digital format (the digital culture), transmitting data on the network (the network culture), presenting the project activity results by means of digital technologies (the ethic culture), the culture of working as a team (the communicative culture), and the culture of managing one's activity (the culture of self-organization). All this characterizes the information competency as the metasubject one (Polichka et al., 2020).

\section{Experience of pedagogical support. The fulfilment of map types by higher educational institution students}

Maps for cultivating the information competency in higher educational institution students are designed for broadcasting the experience of meaning-making, information structuring, depicting the systemic thinking processes, and generating their own digital content when presenting the information.

Let the pedagogical experience of rendering support to the university students in mapping and their fulfilling some types of maps be described below. The authors identify four types of maps: subject maps, meta-subject (mental) maps, portfolio maps as the digital footprint, and maps of start-ups, detailed in Table 1.

Based on the above characteristics of map types, in the period of studies during the pandemic and lockdown, the students were suggested to build maps on various subjects determining their own individual educational routes. As a result of this experimental work, they have come up with some interesting maps. Links to the students' works on creation of maps are given in Table 2. 
Table 1. Types of maps for developing the information competency in higher educational institution students.

\begin{tabular}{|c|c|c|c|}
\hline Subject maps & $\begin{array}{l}\text { Meta-subject } \\
\text { (mental) maps }\end{array}$ & $\begin{array}{l}\text { Portfolio maps as the } \\
\text { digital footprint }\end{array}$ & Start-up maps \\
\hline $\begin{array}{l}\text { Imply collecting and } \\
\text { structuring the } \\
\text { information on the } \\
\text { domain, presenting it as } \\
\text { a diagram of } \\
\text { associations at the } \\
\text { systemic thinking } \\
\text { development level }\end{array}$ & $\begin{array}{l}\text { Incorporate ideas of } \\
\text { supra-subjectness, } \\
\text { reflexivity, and } \\
\text { universalism; they } \\
\text { imply thinking through } \\
\text { the most important } \\
\text { notions and } \\
\text { mastering the tools } \\
\text { underlying any } \\
\text { domain }\end{array}$ & $\begin{array}{l}\text { Are associated with the } \\
\text { digital personal culture; } \\
\text { they imply fulfilling self- } \\
\text { invention strategies, } \\
\text { maintain the profound } \\
\text { unmistakable "digital } \\
\text { footprint" as described in } \\
\text { the authors' earlier studies } \\
\text { (Tabachuk et al., 2020) }\end{array}$ & $\begin{array}{l}\text { Develop students' } \\
\text { abilities to analyse the } \\
\text { information in a critical } \\
\text { manner; they generate } \\
\text { activity and } \\
\text { independence of } \\
\text { students }\end{array}$ \\
\hline \multicolumn{4}{|c|}{ Maps enable one to learn: } \\
\hline $\begin{array}{l}\text { Methods of sorting out } \\
\text { large data volumes }\end{array}$ & $\begin{array}{l}\text { Universal ways of } \\
\text { preadaptation to } \\
\text { uncertainty }\end{array}$ & $\begin{array}{l}\text { Methods of forming the } \\
\text { digital content and } \\
\text { protecting one's identity }\end{array}$ & $\begin{array}{l}\text { Ways of building a } \\
\text { positive attitude to } \\
\text { discovering the world of } \\
\text { the "digit" }\end{array}$ \\
\hline \multicolumn{4}{|c|}{ Maps promote the development of: } \\
\hline $\begin{array}{l}\text { Subject experience of } \\
\text { working with information }\end{array}$ & $\begin{array}{l}\text { Subject experience of } \\
\text { the independent, fast, } \\
\text { and conscious } \\
\text { "transfer", i.e., } \\
\text { performing in the new } \\
\text { conditions }\end{array}$ & $\begin{array}{l}\text { Subject experience of } \\
\text { laying out the individual } \\
\text { educational route in the } \\
\text { digital footprint form }\end{array}$ & $\begin{array}{l}\text { Subject experience of } \\
\text { pedagogical and } \\
\text { information support of } \\
\text { one's own ideas and } \\
\text { projects }\end{array}$ \\
\hline \multicolumn{4}{|c|}{ Indicators of students' achievements in working with maps: } \\
\hline $\begin{array}{l}\text { Culture of working with } \\
\text { information }\end{array}$ & $\begin{array}{l}\text { The achievement of } \\
\text { meta-subject } \\
\text { educational results in } \\
\text { the context of the } \\
\text { activity-based } \\
\text { constituent of the } \\
\text { information } \\
\text { competency }\end{array}$ & $\begin{array}{l}\text { The authors' approach to } \\
\text { self-fulfilment both in the } \\
\text { real and virtual world }\end{array}$ & $\begin{array}{l}\text { The development level } \\
\text { of motivation, reflexivity, } \\
\text { and network thinking, } \\
\text { manifestation of the } \\
\text { Internet activity as } \\
\text { described in the earlier } \\
\text { studies (Tabachuk et } \\
\text { al., 2018) }\end{array}$ \\
\hline
\end{tabular}

Table 2. Examples of different types of maps created by the students.

\begin{tabular}{|c|c|c|c|}
\hline Subject maps & $\begin{array}{l}\text { Meta-subject (mental) } \\
\text { maps }\end{array}$ & $\begin{array}{l}\text { Portfolio maps as the } \\
\text { digital footprint }\end{array}$ & Start-up maps \\
\hline $\begin{array}{l}\text { The map on the } \\
\text { "Information } \\
\text { systems" subject } \\
(2020)\end{array}$ & $\begin{array}{l}\text { The mental map for } \\
\text { selecting resources for } \\
\text { distance learning (joint } \\
\text { work with students) (2020) }\end{array}$ & $\begin{array}{l}\text { The digital footprint } \\
\text { focused on pedagogy: } \\
\text { the portfolio of physics } \\
\text { tricks (2020) }\end{array}$ & $\begin{array}{l}\text { The project in the form of an } \\
\text { interactive module which } \\
\text { has found its own audience } \\
\text { of users (2020) }\end{array}$ \\
\hline
\end{tabular}


The maps designed were evaluated by experts on the part of the teaching community when they were presented within the interim and state final assessment of the students at the university. Then, $100 \%$ of the experts noted the relevance of mapping, particularly in the period of the pandemic, rated the students' work high in terms of their upgrading their own information competency level.

In the period of the pandemic, some events were organized for presenting the results of the students' completing their individual educational routes and broadcasting the subject experience of upgrading the information competency within the annual open university festival, Art-campus of the PSU (2020). Hosted by the Pacific State University, the festival was conducted on Instagram online. One of the events was the "Virtual kaleidoscope of pedagogical student start-ups" where they demonstrated start-ups in the form of individual educational routes, digital footprint, and other projects having won the right for existence and an audience of users of their own.

\section{Experimental test of the efficiency of map plotting in completing individual educational route types while developing the information competency in students}

The efficiency of plotting the maps was tested while the university students completed individual educational route types in the process of developing their information competency. For this, the authors used psychological techniques (llyina, 2020) technique for studying the motivation of learning at higher educational institutions, the technique for identifying the reflexivity development level by A.V. Karpova (2020). The experimental work involved students of years 3 and 5 of training profile 44.03.05 "Pedagogical education" of the Pacific State University. The sampling numbered 100 people. The students of year 3 were asked to create subject and meta-subject (mental) maps, the ones of year 5 - portfolio maps as the digital footprint and startup maps.

For identifying the lines of completing individual educational route types, T.I. llyina's (2020) technique for studying the motivation of learning at higher educational institutions was used. The findings are given in Figure 1.

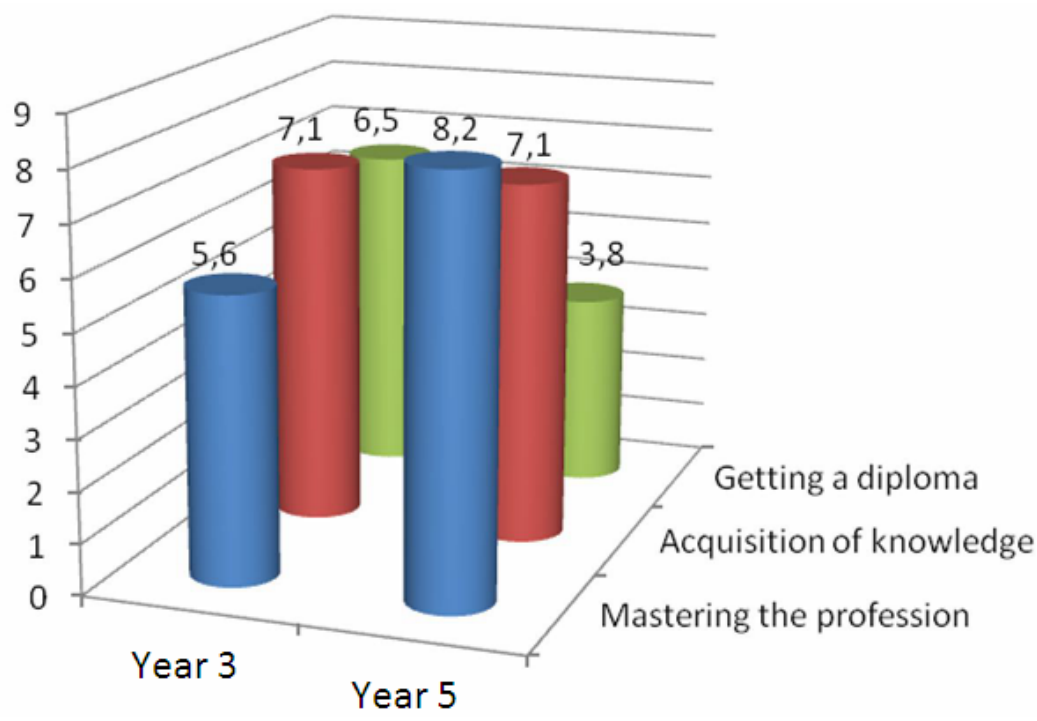

Mastering the profession

Acquisition of knowledge

Getting a diploma

Figure 1. Results of average values broken down to all scales and years of study: T.I. Ilyina's (2020) technique for measuring motivation of learning at higher educational institutions. 
In the third year students, the average indicator is higher in the "acquisition of knowledge" scale - 7,1; next comes "getting a diploma" - 6,5. This is indicative of their high aspiration to gaining professional knowledge, manifestation of inquisitiveness. According to this diagram, in year 5 , the leading objectives are "mastering the profession" - 8,2 and "acquisition of knowledge" - 7,1, while "getting a diploma" is not an end in itself. It is important to have specialized information and sound knowledge for mastering the future profession. T.l. Ilyina's (2020) test points to the students' relevant selection of the profession and being satisfied with it, as well as their focus on self-improvement. The maps serve as a tool for enhancing the learning motivation of the students, their involvement into the process of building individual educational routes for enhancing their information competency.

To find out the students' reflexivity development level as for their own activity, A.V. Karpova's (2020) technique was used, as shown in Figure 2.



Figure 2. Results of percentage values broken down to levels and years of study: A.V. Karpova's (2020) technique for finding out the reflexivity development level.

The analysis of percentage values shows the students of year 3 score highest in the "medium reflexivity development level" scale - 70\%; with the "low level" - 20\% and "high level" - $10 \%$ - following. This indicates the fact that in the students of year 3 , reflection manifests itself in their inclination to analyse the content of

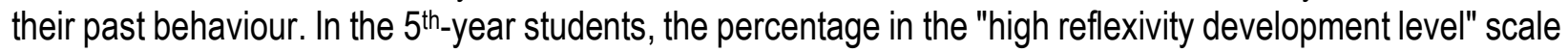
is higher - 55\%; the "medium level", $40 \%$, and "low level", 5\%, coming next. The high reflexivity development level is observed alongside the principal behavioural characteristics: planning the details of one's behaviour carefully, frequently addressing to the future events, and orienting to the future, which accompanies the process of mapping.

The students' higher motivation and reflexivity development level confirm the efficiency of map plotting in completing individual educational route types while cultivating their information competency. 


\section{CONCLUSION}

The study allows us to draw the following conclusions.

It was established that groups of participants have a different structure of experienced fears.

It was found that groups of respondents significantly differ on the indicator characterized by negative expectations regarding social interaction, anxiety and discomfort in the process of social interactions, which makes up the core of the phenomenon of social phobia. Emotional vulnerability, hypersensitivity to adverse incentives are main characteristics of role-playing respondents' emotional sphere. From our point of view, this reflects distancing, their fear of social contacts. Respondents who do not belong to the role-playing movement are significantly more satisfied with social support than role-players respondents.

It was shown that the emergence of social fears of role-players respondents is based on interpersonal factors: tendency to idealize people around them, high expectations of a "good attitude" from others, on the one hand; on the other hand, distrust of people, hostility, inconsistency of affection and tendency to breakdown relations when even the slightest problems appear.

It was established that the role-playing subculture is an important coping mechanism for overcoming social fears. Role-playing is a certain hyper compensation that allows one to manage own inferiority through playing different role-playing images.

Conditions for overcoming social fears of role-playing movement participants are as follows: formation of emotional decentration, decrease in aggressiveness, development of self-esteem, and provision of adequate interpersonal interaction with others. An effective means of teaching to overcome offence and resentment is the socio-psychological training of an integrative type, each direction of which is practiced at three levels: cognitive, emotional and behavioural.

The elaborated model of psychological and pedagogical correction of fears includes emotional and value components that ensure the formation of knowledge, skills and attitudes to existential fears. As a result, students acquire knowledge about their own fears, causes of their occurrence and mechanisms of appearance; skills of constructive behaviour, assessment of traumatic situations, reflection of traumatic situations, regulation of emotional states; value attitude to overcoming of emerging fears and anxieties.

The application of the targeted program of psychological and pedagogical correction of fears among respondents of role-playing movements revealed a decrease in the level of anxiety, manifestation of actual fears, in particular, existential fear of death and socially evaluative fear, as one of the most significant fears.

\section{ACKNOWLEDGMENTS}

The authors express their gratitude to the representatives of the scientific schools known both in Russia and beyond the country (those of I. V. Robert and A. V. Khutorskoy), for having guided them to studies in this area. 


\section{REFERENCES}

Abad-Segura, E., González-Zamar, M.-D., Infante-Moro, J.C. \& Ruipérez García, G. (2020). Sustainable Management of Digital Transformation in Higher Education: Global Research Trends. Sustainability, 12(5), 2107-2125. https://doi.org/10.3390/su12052107

Abulkhanova, K.A. (2014). Methodological principle of subject: a study of the life path of personality. Psychological Journal, 35(2), 5-18.

Agheev, A.I., Averiyanov, M.A., Evtushenko, S.N. \& Kochetova, E.Yu. (2017). Digital society: architecture, principles, vision. Economic Strategies, 1, 114-125.

Art-campus of the PSU (2020). In Russian. Retrieved from: http://pnu.edu.ru/ru/news/2020-05-14-PNU/

Asmolov, A.G., Shekhter, E.D. \& Chernorizov, A.M. (2017). Preadaptation to uncertainty as a navigation strategy of developing systems: routes of evolution. Questions of Psychology: Pedagoghika publishers, 4, 3-26.

Atlas of new professions. (2020). In Russian. Retrieved from: http://atlas 100.rul

Avdeev, V.A., Avdeeva, O.A., Shagieva, R.V., Smirnova, V.V., Mashkin, N.A., \& Taradonov, S.V. (2019). The mechanism of legal regulation in the conditions of globalization and formation of information environment. Regional aspect. Journal of Environmental Management and Tourism, 10(7), 15171521.

Bayanova, A.R., Sivova, I.V., Kamasheva, Y.L., Popova, O.V., Semyanov, E.V., Shagieva, R.V., \& Yusupov, I.M. (2020). Student online services consumption: Routine practices or mistrust to digital service? Contemporary Educational Technology, 11(1), 47-54. https://doi.org/10.30935/cet.641767

Bayanova, A.R., Vodenko, K.V., Sizova, Zh.M., Chistyakov, A.A., Prokopiev, A.I., \& Vasbieva, D.G. (2019). A philosophical view of organizational culture in contemporary universities. European Journal of Science and Theology, 15(3), 121-131.

Bubnova, I.S., Khvatova, M.A., Chernik, V.E., Popova, O.V., Prokopyev, A.I., Naumov, P.Yu., \& Babarykin, O.V. (2018). Research of Professional Activity Features of Ecologist at Carrying Out Public Ecological Examination. Ekoloji, 106, 999-1006, Article No: e106183.

Cuénot, L. (1914). Theory of preadaptation. Priroda ("Nature"), 1, 1297-1304. In Russian. Retrieved from: http://www.paleobot.ru/pdf/4-6 2013 8.pdf

Huxley, J. (1942). Evolution. Modern Synthesis. Leningrad: Allen \& Unwin.

ICT competency framework for teachers. (2019). UNESCO guidelines. In Russian. Retrieved from: https://iite.unesco.org/wp-content/uploads/2019/05/ICT-CFT-Version-3-Russian-1.pdf

Ilyina, T.I. (2020). Methodology for studying the motivation of studying at a university. In Russian. Retrieved from: http://testoteka.narod.ru/ms/1/05.html

Karakozov, S.D. \& Uvarov, A.Yu. (2016). Successful informational support = transformation of the process of learning within the digital educational environment. Problems of Modern Education, 2, 719.

Kardis, M., Sturak, P., Králik, R., Trong, D.N., Korzhuev, A.V., Kryukova, N.I. (2019). A sociologicalreligious probe into contemporary global salafi jihadism. European Journal of Science and Theology, 15(4), 113-125.

Karpova, A.V. (2020). Methodology for diagnosing the level of development of reflexivity. In Russian. Retrieved from: https://mtests.ru/tests/personality/metodika-diagnostiki-urovnya-razvitiyarefleksivnosti-oprosnik-karpova-a-v/

Khairullina, E.R., Shubovich, M.M., Bogdanova, V.I., Slepneva, E.V., Mashkin, N.A., \& Rodyukova, T.N. (2020). Modern student youth civic identity: Political activity or social responsibility? Opcion, 36(Special Edition 27), 1703-1717. 
Khutorskoy, A.V. (2005). The technique of learner-centered teaching. How to teach each student in a different way? Moscow: Vlados-Press publishers.

Kovaleva, T.M., Klimova, T.A., Lazareva, L.I., Mitroshina, T.M., Tyumina, M.V. (2018). Personal resource mapping as a means of work of tutors. Moscow: Resource publishers.

Kutuev, R.A., Mashkin, N.A., Yevgrafova, O.G., Morozov, A.V., Zakharova, A.N., \& Parkhaev, V.T. (2017). Methodological guidance of educational monitoring effectiveness. Modern journal of language teaching methods, 7(3), 405-410.

Makarova, E.V., Kryukova, N.I., Sizova, Z.M., Grinenko, A.V., Erofeeva, M.A., and Bukalerova, L.A. (2019). Divergence of supreme values of Russian world and western civilization social and philosophical analysis. European Journal of Science and Theology, 15(3), 97-107.

Orekhovskaya, N.A., Chistyakov, A.A., Kryukova, N.I., Krokhina, J.A., Ospennikov, Y.V., \& Makarova, E.V. (2019). Orthodoxy and modernity their contact facets in Russian society. European Journal of Science and Theology, 15(2), 67-77.

Ovsyanitskaya, L.Yu. (2018). Pedagogic regularities and principles of forming the information competency in health specialists in conditions of digital transformation of processes in education and healthcare. Bulletin of Tomsk State University, 4, 152-157. https://doi.org/10.17223/15617793/433/21

Passport of the national project "Education". (2019). In Russian. Retrieved from: http://static.government.ru/media/files/UuG1ErcOWtifOFCsqdLsLxC8oPFDkmBB.pdf

Piralova O.F., Gerasimenko S.A., Kuznetsov V.V., Popova O.V., Subbotin G.V., Kolomyts O.G., \& Mashkin N.A. (2020). Gaming Industry Trends in new Generation Specialist Training in University Environment. Journal of Environmental Treatment Techniques, 8(3), 1132-1135.

Podymov, N.A., Nikoghosyan, M.A., Stolyarova, A.N., Narutto, S.V., Mashkin, N.A., Martynenko, S.E., Paznikova, Z.I., \& Varenik, P.K. (2019). University New Educational Reality in Disruptive Technologies Context. Journal of Environmental Treatment Techniques, 7(4), 664-668.

Polichka, A.E., Malykhina, O.A., Karpova, I.V. \& Tabachuk, N.P. (2020). Modern problems of education in IT and mathematics: scientific and methodological bases of improving the professional competence of mathematics teachers. Khabarovsk: publishing house of the Pacific State University.

Portal "Scientific Russia". (2020). The pandemic of coronavirus infection: psychological and ethic consequences. In Russian. Retrieved from: https://scientificrussia.ru/articles/pandemiyakoronavirusnoj-infektsii-psihologicheskie-i-eticheskie-posledstviya

Prokofieva, E.N., Erdyneyeva, K.G., Galushkin, A.A., Prokopyev, A.l., Prasolov, V.I., Ashmarina, S.I., Ilkevich B., \& Kubiatko, M. (2018). Risk based ecological economics to engineering students. Eurasia Journal of Mathematics, Science and Technology Education, 14(3), 753-764. https://doi.org/10.12973/ejmste/80903

Recommendations of the Russian Psychological Society due to the spread of COVID-19. (2020). In Russian. Retrieved from: http://psyrus.ru/news/news_rpo/unit/8461/

Robert, I.V. (2020). Axiological approach to the development of education in conditions of the digital paradigm. Pedagogical Informatics, 2, 89-113.

Smakotina, N.L. (2017). Transformation of education in conditions of globalization: opportunities and risks. Values and Meanings, 6(52), 21-28.

Sofronova, N.V. \& Belchusov, A.A. (2019). Theory and methods of teaching IT: a study guide for higher educational institutions. Moscow: Yurait publishers.

Soltovets, E., Chigisheva, O., \& Dmitrova, A. (2020). The role of mentoring in digital literacy development of doctoral students at British universities. EURASIA Journal of Mathematics, Science and Technology Education, 16(4), em1839. https://doi.org/10.29333/ejmste/117782 
Soltovets, E., Chigisheva, O., \& Dubover, D. (2019). Foreign language e-course as informal learning tool for digital literacy development. Dilemas contemporaneos-educacion politica y valores, 6(3), Art. 50.

Tabachuk, N.P. (2016). Online resources as a modern means of students' information competence development. International Journal of Economics and Education, 2(4), 90-94.

Tabachuk, N.P. (2019). Information competency of a student's personality as a sociocultural phenomenon of digital society. Khabarovsk: publishing house of the Pacific State University, 2019.

Tabachuk, N.P., Ledovskikh, I.A., Shulika, N., Kazinets, V.A. \& Polichka, A.E. (2018). Internet Activity and Internet Addiction: Where is the Borderline in Developing One's Information Competency? EURASIA Journal of Mathematics, Science and Technology Education, 14(12), em164. https://doi.org/10.29333/ejmste/97828

Tabachuk, N.P., Polichka, A.E., Dvoryankina, E.K. \& Karpova, I.V. (2020). "Digital Image" in the Methodological System of Information Competency Development by University Students. International Journal of Applied Exercise Physiology, 9(2), 81-87.

The digital footprint focused on pedagogy: the portfolio of physics tricks (2020). In Russian. Retrieved from: http://2305375.mya5.rul

The map on the "Information systems" subject (2020). In Russian. Retrieved from: http://2305479.mya5.rul

The mental map for selecting resources for distance learning (joint work with students) (2020). In Russian. Retrieved from: http://linoit.com/users/tabachuk/canvases/Resurs

The project in the form of an interactive module which has found its own audience of users (2020). In Russian. Retrieved from: https://learningapps.org/display?v=puanxg8wn17

Tulchinskiy, G.L. (2017). Digital transformation of education: challenges to higher school. Russian Journal of Philosophical Sciences, 6, 121-136.

Vinogradova, G.A., Akhmadieva, R.Sh., Konovalova, V.M., Spirina, E.V., Kalugina, O.A., Erdyneeva, K.G., Popova, N.N., \& Mashkin, N.A. (2018). Releasers as Factor of Student Ecological Focus Formation. Ekoloji, 27(106), 1409-1415.

Yakimanskaya, I.S. (2007). Psychological and pedagogical conditions of establishment of schoolchildren's individual learning strategies. Moscow: Obninsk: IG-SOCIN.

Yurlovskaya, I.A. \& Guchmazova, K.P. (2016). Students' individual educational route as a mechanism of educational process of the modern pedagogical higher educational institution. World of Science (the Internet-based journal), 4(2). In Russian. Retrieved from: http://mir-nauki.com/PDF/24PDMN216.pdf

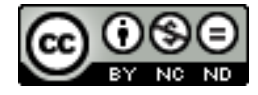

This work is licensed under a Attribution-NonCommercial-NoDerivatives 4.0 International (CC BY-NC-ND 4.0). 